\title{
Contemporary Knowledge and Musical Creation: Ethic and Paradigms
}

\section{Conhecimento Contemporâneo e Criação Musical: Ética e Paradigmas ${ }^{1}$}

\author{
Ilza Nogueira \\ Universidade Federal da Paraíba \\ nogueira.ilza@gmail.com
}

Abstract: In this essay, the author reflects upon musical knowledge of the last thirty five years under the light of contemporary philosophy (Gilles Deleuze, Félix Guatarri and Sílvio Gallo), demonstrating, through music analysis, how the evolution of compositional thought from 1980 to 2010 accompanies ethical and paradigmatic concepts which apply to the broad intellectual thought of the timeperiod. Works by three composers from Bahia - Ernst Widmer (1927-1990), Paulo Costa Lima (b. 1954) and Paulo Rios Filho (b. 1985) - serve the analytical demonstration, which leads to a conclusive reflection on the interdependence of artistic creation and contemporary strategies of knowledge production.

Keywords: crisis of contemporaneity; contemporary knowledge; music analysis; composers from Bahia.

Resumo: Neste ensaio, a autora reflete sobre o conhecimento musical dos últimos trinta e cinco anos sob a luz da filosofia contemporânea (Gilles Deleuze, Félix Guatarri and Sílvio Gallo), demonstrando, através da análise musical, como a evolução do pensamento composicional de 1980 a 2010 acompanhou conceitos éticos e paradigmáticos daquele período de tempo. Obras de três compositores da Bahia - Ernst Widmer (1927-1990), Paulo Costa Lima (1954-) e Paulo Rios Filho (1985-) - servem à demonstração analítica, levando a uma reflexão conclusiva sobre a imbricação entre a criação artística e as estratégias contemporâneas de produção do conhecimento.

Palavras-chave: crise da contemporaneidade; conhecimento contemporâneo; análise musical; compositores da Bahia.

${ }^{1}$ Translated by Heather Dea Jennings 


\section{1 - Crisis of Contemporaneity}

"Crisis of contemporaneity" is an ever-present expression in the scope of artistic production. As long as I have been in the field of music (since in the distant 1960's), I have been familiar with a resurgent debate concerning a current crisis of contemporary music. The Art Research Journal (ARJ) facilitated a rethinking of the topic, defining it as a theme in its second edition (vol. 2/1, Jan. - June 2015), "Music and the crisis of contemporaneity." 1 The central word contains a stimulating puzzle for the authors: "crisis," a term owing to its Greek origin $\left(\right.$ Koí $\left.\sigma \varsigma^{2}\right)$, the connotation of difficulty in deciding and judging.

What types of difficulties are set off in contemporary music? For whom? Why? Consequent answers to these questions will, necessarily, encompass a wide gamut of knowledge, not only in the field of music but in different areas of the exact, social and biological sciences. Theories of music, of systems, of aesthetics, of culture, of cognition, of social psychology, etc., form a legitimate ideological crossroads, where the authors of the texts related to the theme of the ARJ certainly found themselves in a true crisis of decision or choice of multidisciplinary approaches or transdisciplinary readings.

I participated in a group of musicians with various backgrounds (theorists, musicologists, educators, performers and composers) who were asked to create a synopsis which could stimulate and guide the articles solicited by the journal. The text we conceived ${ }^{3}$ takes note that the musical aesthetics of the twenty-first century are an "open field." If, on the one hand, we can see the "ebbing of radicalism" against the engagement with "an expressiveness that was considered abandoned since modernity," on the other hand, the development of sonology brings the possibility of considering music as "a case in the multi-expressive sound arts." In a world globalized by communication and by informational technology, the "redefinition of the role and meaning of music in contemporaneity" seems to be the challenge raised by the choice of the theme.

In today's world, the mass media exercise a great power-grab on modes of existence; they define ways of thinking, acting and feeling and influence our choices and tastes. Using an expression from contemporary sociology and psychology, this is the process of subjectification, ${ }^{4}$ characteristic of contemporaneity: that is, the way by which we relate to ourselves and with our historical world. It is the process of subjectification which conditions the creation of subjectivity, or, in other words, our existential territory, in a constant process of construction, expressing values which guide our strategies of knowledge production. Giving the last word to Felix Guatarri, "subjectivity is essentially constructed and modeled in the social record" (Guatarri \& Rolnik 1996, p. 31). However, it is a "process of singularization," or an "affirmation of values in a 
specific record, independently of the scales of value which surround and survey us from every side." (Ibid., 47).

As for the strategies of knowledge production, we cannot forget the fact that we share them socially, creating established practices and procedures (therefore, "paradigms" - in other words, values), legitimated and effective in each historical time-period. Social sharing is responsible for the constant renewal of paradigms, in the process of subjectification. In this process, we must register the importance of the ethical dimension, ${ }^{5}$ that is, the values which direct our strategies of knowledge production.

There exists, therefore, a relation of complementarity and reciprocity between ethics and paradigms. Subjectified, the paradigmatic strategies of knowledge production express the values which guide our modes of existence (or, the ethics of the subject). Paradigms, therefore, are not neutral. They reflect the dominant modes of subjectification in a determined historical context.

If the subjective experience of the current period corresponds to the refinement of technological expertise and to the globalization of knowledge - that is, the gravitation of the social and cultural processes of a worldwide character over those of a national character - it is supposed that the values which guide contemporary knowledge production must consequently suffer some type of cultural axis deviation, to satisfy the expectation of a world voracious for immediate and long-range intercommunication. Such intercommunication defines its paradigmatic model of reasoning, producing and communicating ideas and rationales.

Yes, contemporary art responds to the effects of the world globalized by communication and by technology, where constant reinvention and increased complexity of the strategies of knowledge production imply continued transformation and permanent questioning of values and ideas which guide artistic creation and appreciation. It appears to be there the heart of the "crisis" surrounding the apprehension and comprehension of the music of our days, an aesthetic product through which a form of communication is made possible (or not).

\section{2 - Contemporary knowledge}

Definition of the paradigm which determines the production of contemporary knowledge, of which musical creation is a part, presupposes an understanding of the way in which our set of social practices produces a mold of how we relate to ourselves and to the world; it presumes understanding how the processes of subjectification of this historic period guides us to the proposal of new strategies of knowledge production. 
In his book Chaosmosis: An Ethico-aesthetic Paradigm, Guattari explains the distinction between modern and post-modern knowledge and how it corresponds to the distinction between a "scientistic paradigm" (that which is produced in the context of writing) and an "ethical-aesthetic paradigm" (defined by communication and informatics technologies).

The theory of traditional knowledge defines the "scientistic paradigm" by the metaphor of the tree, whose roots (the true premises) are anchored to a solid trunk (philosophy) by which many branches spread, reproducing the fragmentation of knowledge in specializations: the scientific concepts of modernity. The branches are the diverse sciences, which only interrelate by the common trunk, its historical genealogy. The type of indirect association between the branching of diverse specializations via the trunk or center of knowledge assumes hierarchies. The upper unit (the trunk) determines the connections, establishing them previously and giving them meaning. The high level of commitment to the philosophical foundation allows, however, for discourse and unifying principles.

As for the "ethical-aesthetic paradigm," Deleuze and Guattari define it via the metaphor of the rhizome, where various areas of knowledge are represented by countless fibrous lines. They interlace, forming a complex set, whose elements necessarily deliver to one another, as well as to outside their own set.

Unlike trees or their roots, the rhizome connects any point to any other point, and its traits are not necessarily linked to traits of the same nature. [...] It is composed not of units but of dimensions, or rather directions in motion. It has neither beginning nor end, but always a middle (milieu) from which it grows and which it overspills. [...] Unlike the tree, the rhizome is not the object of reproduction: neither external reproduction as image-tree nor internal reproduction as tree-structure. The rhizome is an anti-genealogy. [...] Unlike tracings, the rhizome pertains to a map that must be produced, constructed, a map that is always detachable, connectable, reversible, modifiable, and has multiple entryways and exits and its own lines of flight. [...] In contrast to centered (even poly-centric) systems with hierarchical modes of communication and pre-established paths, the rhizome is an acentered, nonhierarchical, nonsignifying system without a General and without an organizing memory or central automaton, defined solely by a circulation of states. (Deleuze \& Guatarri 1995$, p.21. $)^{6}$

Sílvio Gallo (1998) frames this definition by Deleuze and Guatarri in different words, determining the principal aspects in which the metaphor of the rhizome subverts the order of the arboreal metaphor. 1st - with the tree, the relationships between the branches are mediated by the trunk, obeying a determined hierarchy and following an intrinsic order, whereas any point of a rhizome can be connected to any other; 2nd - while the tree is a pseudo- 
multiplicity of elements which can be reduced to the one and complete "tree," the rhizome is always a multiplicity which does not reduce to a unit; 3rd - while the tree's hierarchy of relationships induces it to their homogenization, in the rhizome, any connection is possible, since it is governed by heterogeneity; 4th while the arborescent paradigm refers to itself, because the logic of the tree is that of the copy, of reproduction, the logic of the rhizome is that of becoming, that of exploration, that of discovery, because it can be approached from a multitude of points and refer to any of the others.

Breaking with the very hierarchy of the tree paradigm (both in the aspect of importance as well as in the aspect of priorities), the rhizome calls for a new form of passage between its many becomings. Also according to Gallo, in the rhizomatic model, this transit makes a transverse path amongst the multiple integrated knowledges into new forms of contemporary thinking: "just as the synapses travel via the neurons, a seemingly chaotic journey which constructs its/their sense/s to the measure in which we develop the fractal equation." (Ibid.) The rhizomatic transversability, explains Gallo, builds possible passages within a multiplicity of knowledges, without seeking to integrate them artificially, but, rather, to establish infinite poly-competencies.

This is the crisis of postmodernity. It is based, therefore, in the divorce of the sciences from a systematic vision (philosophical) of the world. It is a crisis which, according to Professor João Antônio de Paula (2008, p. 10), "continues to be relevant."

\section{3 - Musical Creation}

As stated by Lawrence Kramer, "music always forms an expression of the engagement with world and time [...]; it's the trace of witnessing and stewardship that for Heidegger was synonymous, or should be synonymous, with Dasein, human being in the world." "Music comes as part of a dense, branching cluster of values, practices, judgements, social relationships, cultural practices, types of identities, flow of feelings and attitude - the list goes on. It is an open-ended list; it cannot be completed." 7 Seeing music as a feature of the composer's existential relationship with its historical and cultural context is the task of musicology. Understanding music, however, must start with an ontology of the present, calling in question the relationship between musical creation and the historical context which it concerns.

For many years, my work in music analysis has been concentrated on the production of composers in the Brazilian state of Bahia. Most recently, it has been focusing the intimate relationship between music, time period and culture. I bring here a short testimony about how this relationship has been developed in 
the concert music of Bahia in the last 35 years. In the synopsis conceived by the ARJ, this period was characterized by the reflux of the experimentalist radicalities which defined the beginning of the second half of the twentieth century. In just a few music examples, I intend to demonstrate how a compositional idea intimately bound to its cultural time and space may also be understood as pertinent to the paradigmatic concepts of knowledge production which social psychology defines for the turn of the twentieth to the twenty-first century.

Before I engage in the discussion of the music, I want to contextualize it in its historical and cultural moment. The compositional production of Bahia begins to reverberate nationally after the second half of the 1960s. A key role in this recognition was played by the composition teaching developed by Ernst Widmer, a Swiss composer who settled in Salvador in 1956. Widmer was a professor at the School of Music at the Universidade Federal de Bahia (UFBA). This school was founded in 1954 by Hans-Joachim Koellreutter, and it took in no fewer than 27 European professors during the eight years of his administration (1954-1962): Germans (for the most part), Swiss, Hungarians and Italians. By contrast, the majority of the young students, which made up the Composers Group of Bahia, were from the countryside (Lindembergue Cardoso, Jamary Oliveira, Tom Zé and Agnaldo Ribeiro). They were imbued, therefore, in a musical culture that was for the most part regionally folkloric. The generation immediately following (in which Paulo Lima and myself are found) grew in the syncretic cultural space of the Recôncavo where the heritage of the Portuguese and African Diaspora would dialogue.

During the time in which the young Bahian composers academically absorbed European musical culture, with emphasis on contemporary vanguard, the Europeans who led the Group, Ernst Widmer and Walter Smetak, ${ }^{8}$ took the opposite route: they allowed themselves to be influenced by the regional culture. This two-way transit between the Central European culture and the miscegenated Bahian culture led to the construction of an identity in the concerto music of Bahia, based on interculturalism and in the recontextualization of traditions. This resulted in an aesthetic conception defined by the bringing together of technique and lyricism, seriousness and humor, adjustment and freedom, standardization and originality. The ethical values, which guided this design of ambiguities, were the awareness of belonging and the destruction of cultural hierarchies, bringing recognition of regional traditions to the level of the hegemonic canons of Central Europe and North America.

I now consider the compositional processes of three authors who represent different generations of Bahian composers: Ernst Widmer (Aarau, 1927-1990), Paulo Costa Lima (Salvador, b. 1954) and Paulo Rios Filho (Salvador, b. 1985), forming a professor-student relationship chain. 
From Ernst Widmer, we observe the motivic procedure of his Duo, opus 127, for violin and piano, a piece from 1980. Only one melodic motivic corresponding to the tetrachordal series D-C\#-B-G\# - is responsible for the high cohesion of the three movements. A compositional procedure of great contextual consistency is carried out via the saturation of the generating motive, presented with a great variety of procedures - inversions, retrogrades, transpositions, reduction to trichordal submotives - and reproduced in distinctive hierarchical layers of the musical texture, according to the tradition of the Second Viennese School. We can observe the unfolding of this motive in the phrases which begin the first, second and third movements (Figures 1, 2 and 3) and in the ending phrase of the work (Figure 4).

The motivic elaboration via the techniques of retrograde, inversion, transposition and nesting reveals that organicity is a paradigmatic concept governing the compositional process.

The generative motive of the Duo is an archetypical melodic structure in the traditional music of the Brazilian northeastern "Sertão," rhythmic profile of the second movement (Figure 2), articulating $7+9$ units in 2 $+2+3$, alludes to the "Vassi," an archetypical rhythmic structure of the Shango's Alujá (a sequence of beats articulated in 5+7: $2+2+1+2+2+2+1$ ). Thus, one can see that elements of different Northeastern traditions (Sertaneja and AfroBahiana) have been joined together in an organicist procedure inherited from the Central-European tradition.

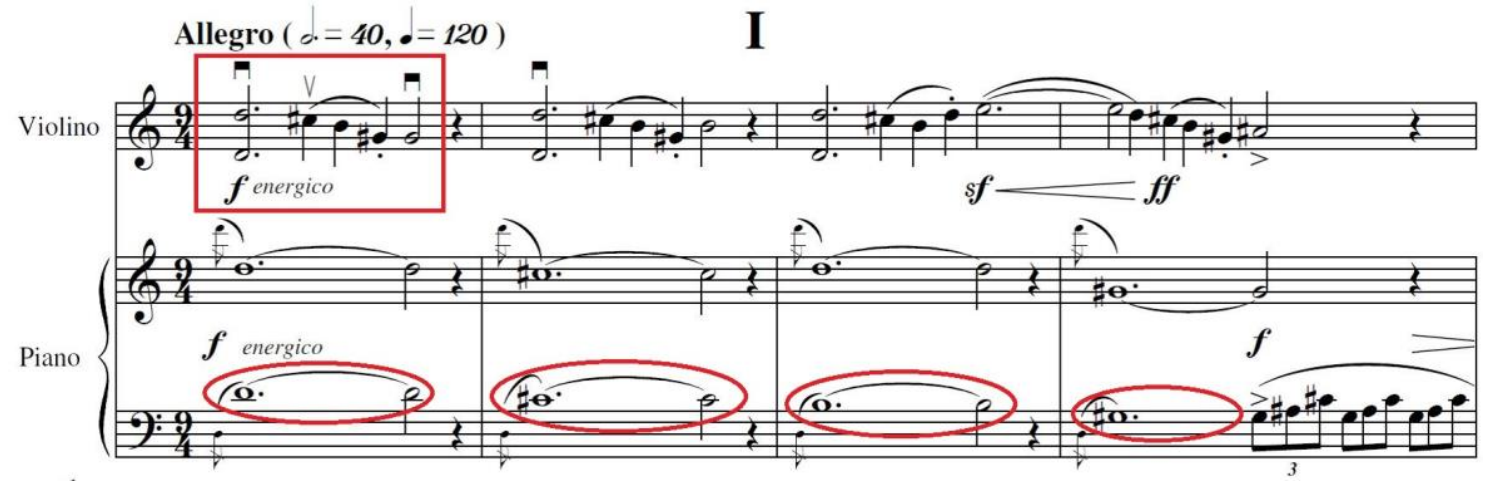

Figure 1: Theme of the first movement (mm. 1-4) 


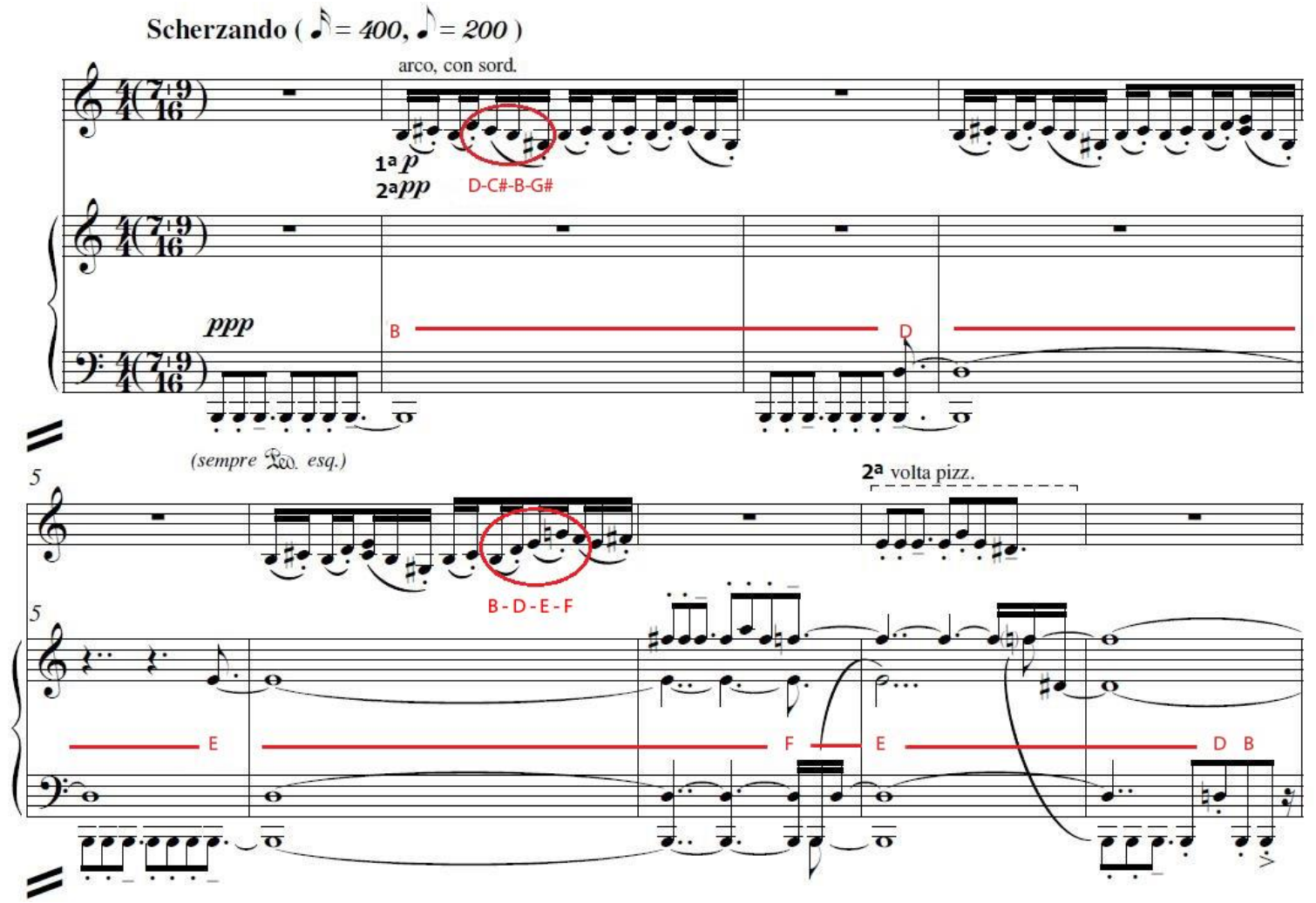

Figure 2: Theme of the second movement (mm. 1 - 9)

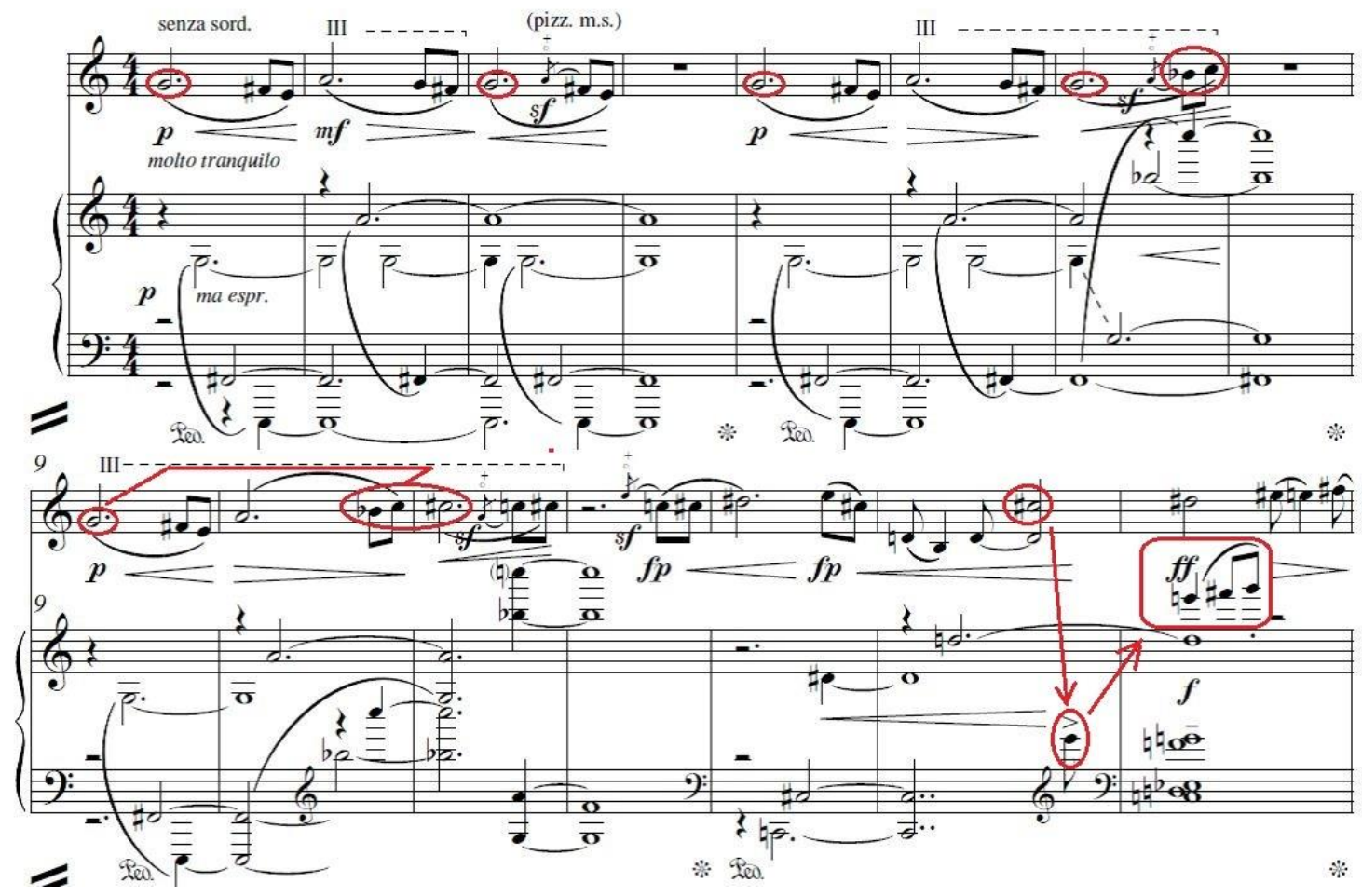

Figure 3: Theme of the third movement (mm. 1 - 12) 


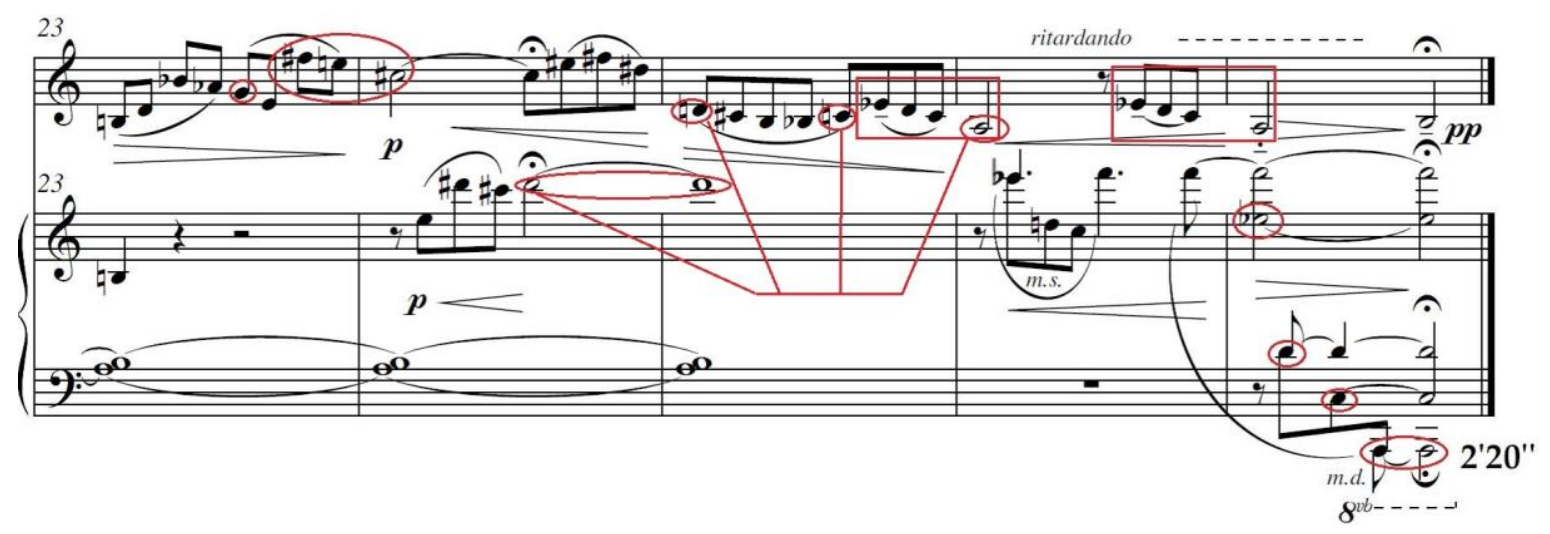

Figure 4: Ending phrase of the third movement (mm. 25 - 27)

We now turn our attention to the structural aspects of the piece Atotô do L'Homme Armé, by Paulo Lima. Conceived for a group of mixed instrumentation (2fl., ob., cl., bn., tpt., pf., 2perc., vn., va., vc., cb.), the piece was written in 1993. According to the composer, the work proposes a dialogue between two ancestral warriors: Shango, the god of fire, of the lightening and storms, from the Yuruba pantheon, and a medieval knight. Lima defines the piece as "a musical reflection about the peace building via differences; a type of image of Bahia itself, a place where this has been happening for centuries."10 This ideology is articulated through a referential and intertextual compositional procedure.

The medieval knight is symbolized by the fifteenth-century song " L'Homme Armé" (Figure 5), one of the canons of Eurocentric musical culture.

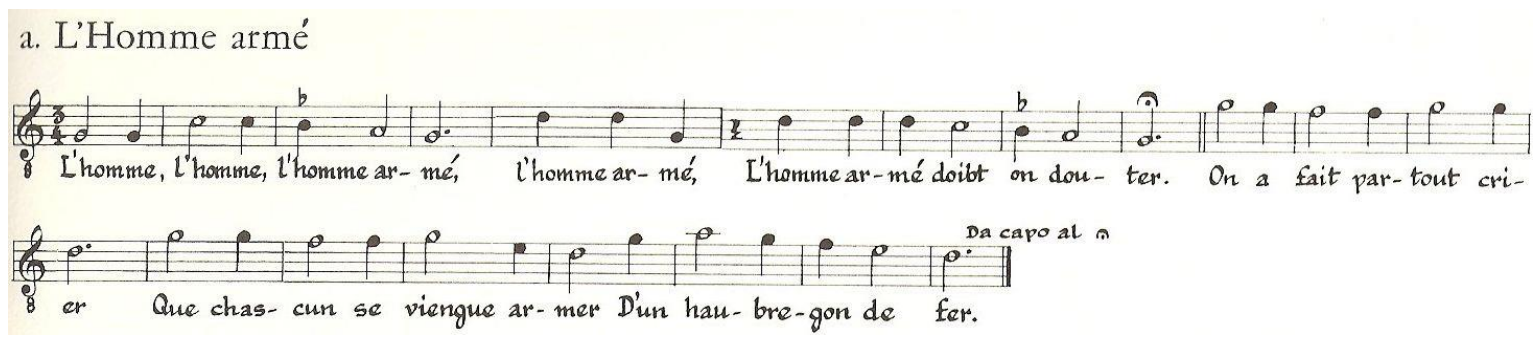

Figure 5: L'Homme Armé (In: APEL, D. Historical Anthology of Music. Cambridge: HUP, 1977, vol. 1, p. 71)

Shango is represented by the Alujá (Figure 6): the rhythmic pattern which we have already seen (the irregular subdivision of 12 beats in $5+7$, carried out through the $[2,2,1 / 2,2,2,1]$ articulation). 
Alujá de Kangô

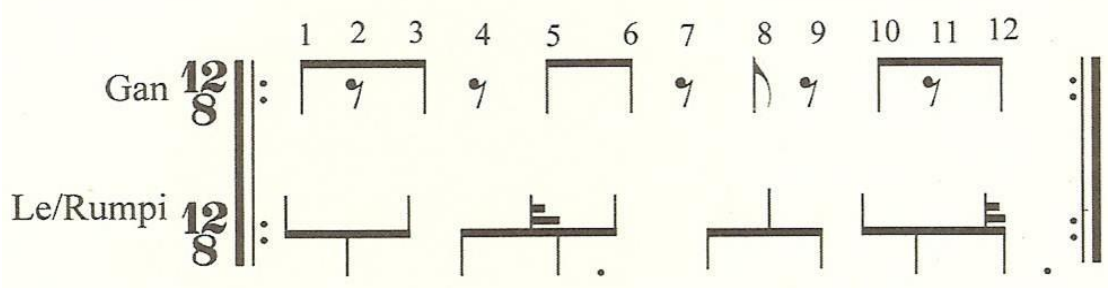

Figure 6: Shango's Alujá (In: Costa Lima 2005, p. 200)

The work syncretizes these two references into a hybrid product, shaped with an adaptation of the Aluja rhythm to the melodic outline of the song "L'Homme Armé." The example in Figure 7 shows this hybridization in the first phrase. The music begins with the berimbau. Its sonority, figurative of the symbiosis between dance and fight, stimulates narratives focusing the AfroBahian cultural scene. ${ }^{11}$

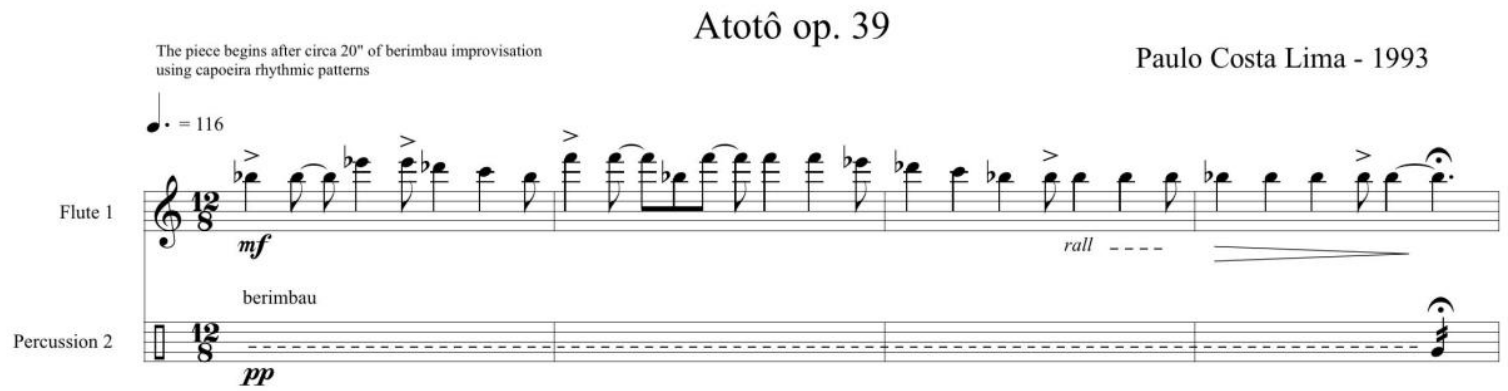

Figure 7: Paulo Costa Lima, Atotô op. 39, mm. 1 -4

What can be observed is a procedure of fusion of the appropriated elements (the melodic line and the rhythmic pattern), which compromises their identities and displaces them from their original signifying contexts. We could even fantasize that the hybridism of this musical configuration represents a dancing knight wielding an oshe ${ }^{12}$, or, a stiff Shango in a dorian armor; parodic, carnivalized types, set to the ironic satire and humor which characterizes the music of Paulo Lima.

In this work, the melodic borrowing is disfigured in a continuous reshaping, which comes together and moves apart from the original outline. In one place, the composer evokes the model, in the other, he resets the model in motivic progressions. In yet another place, the model dematerializes completely in scalar structures, which do not even correspond to the original modal context. 
The alujá is also decomposed in frequent metric modulations, implying in multiple reconfigurations of the original asymmetry. As in the musical discourse of Widmer, that of Paulo Lima is based on procedures of variation, setting a mobile process of successive, non-systematic, unpredictable and fleeting transformations.

The large-scale structure of this piece conforms to a structural project in three sections $\left(\mathrm{A} / \mathrm{B} / \mathrm{A}^{\prime}\right)$, which in turn conform to different states of spirit. The " $\mathrm{A}$ " section establishes the climate of a "dancing frenzy," with a predominantly homophonic texture of modulating density, highlighting the caricatural expression of the bizarre fusion of the alujá with the medieval song (Figure 8).
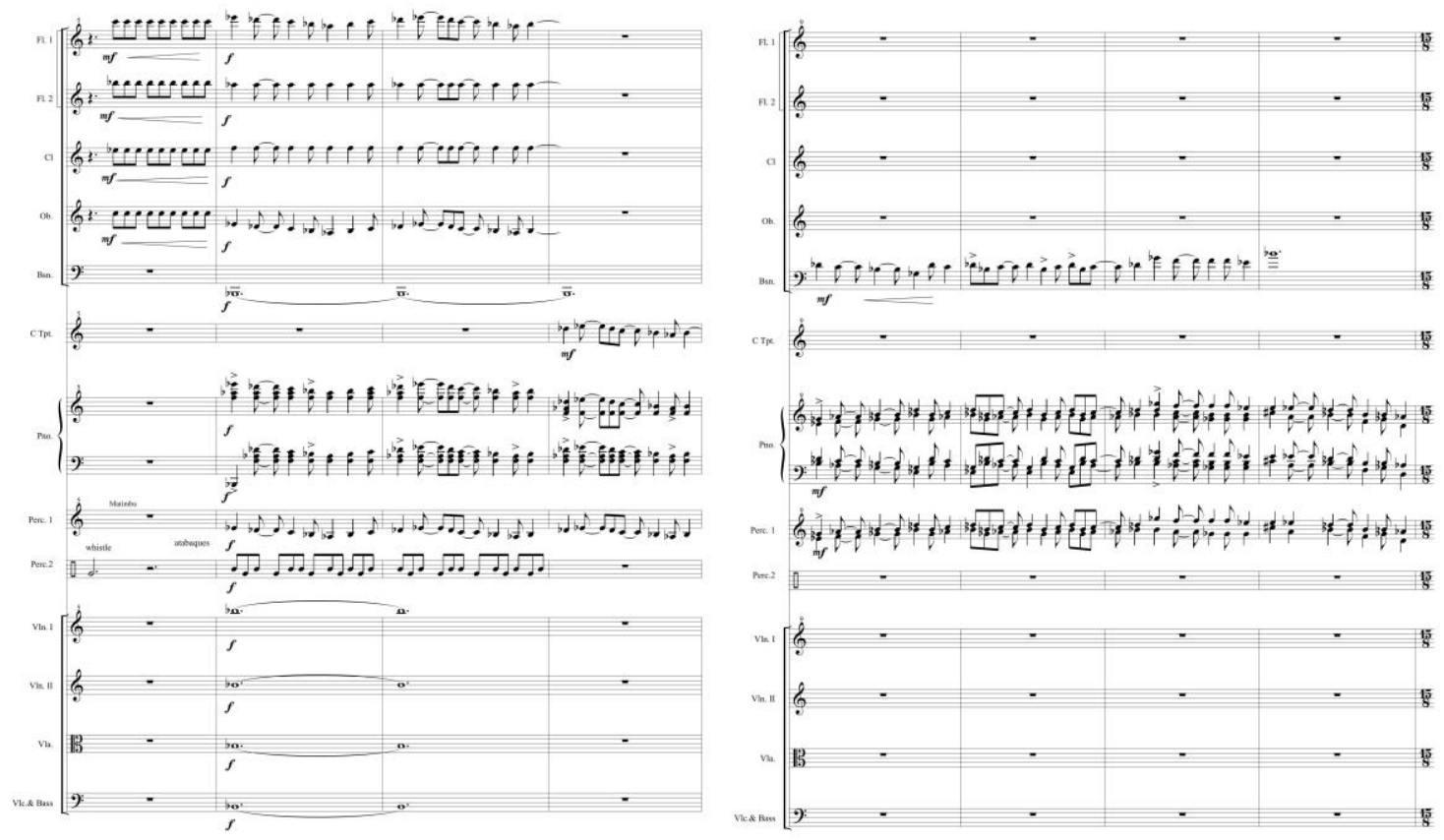

Figure 8: Paulo Costa Lima, Atotô op. 39, excerpt from Section A (mm. 5 - 12)

The central section ${ }^{13}$ establishes a new environment. The previous rhythmic agitation yields to a type of "soundscape" in a piu calmo tempo. Lyrical solos improvisational in character, along with timbristic effects materialize into a type of truce in the continuous transfiguration of the references, in a climate of relaxation of the preceding tensions (Figure 9). 

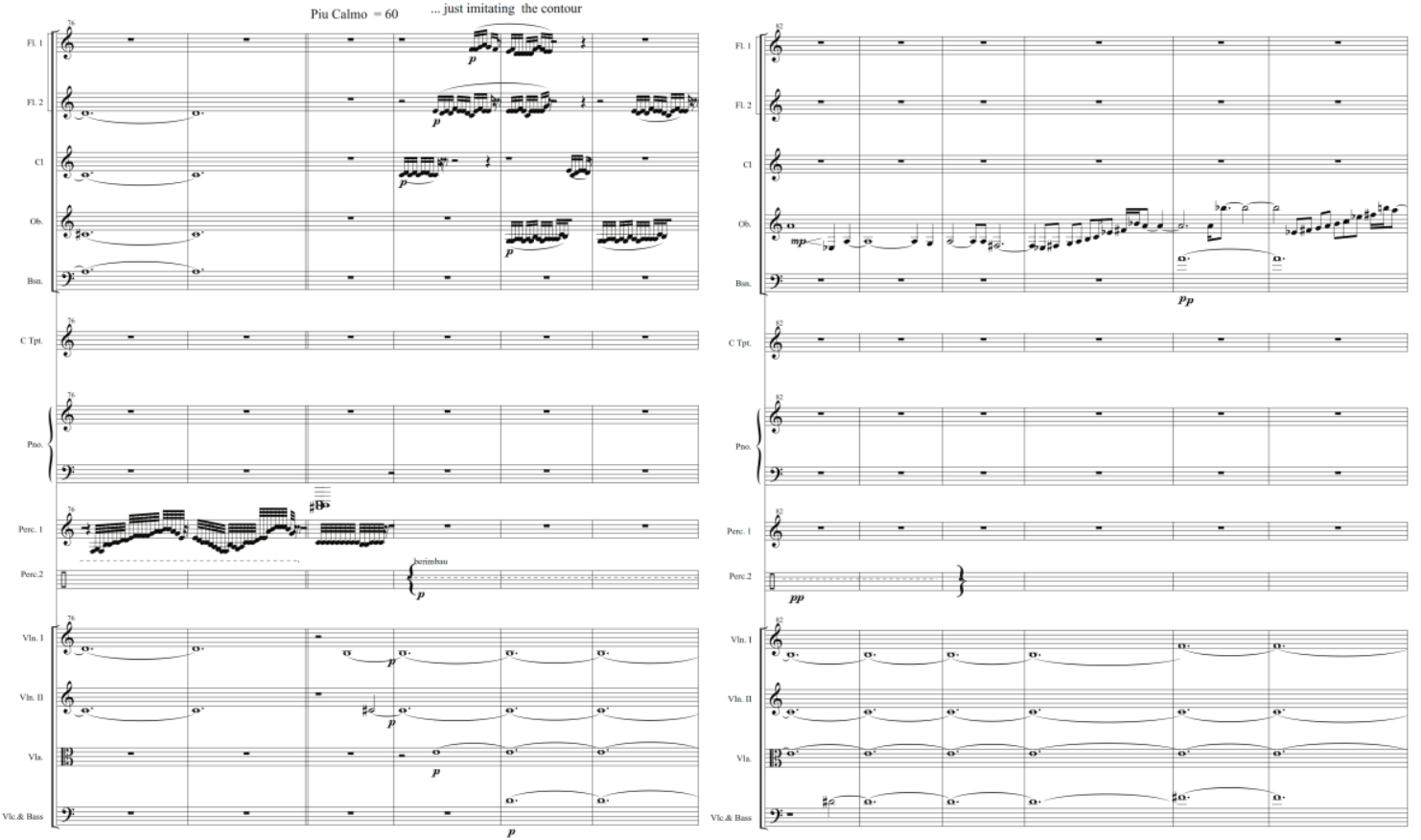

Figure 9: Paulo Costa Lima, Atotô op. 39, beginning excerpt from Section B (mm. 78 - 87)

In the ending section, the return to the "dance" is already less characteristic and impetuous. The rhythm becomes more symmetric, while the modal reference yields to other harmonic contexts such as octatonic symmetries (Figure 10).

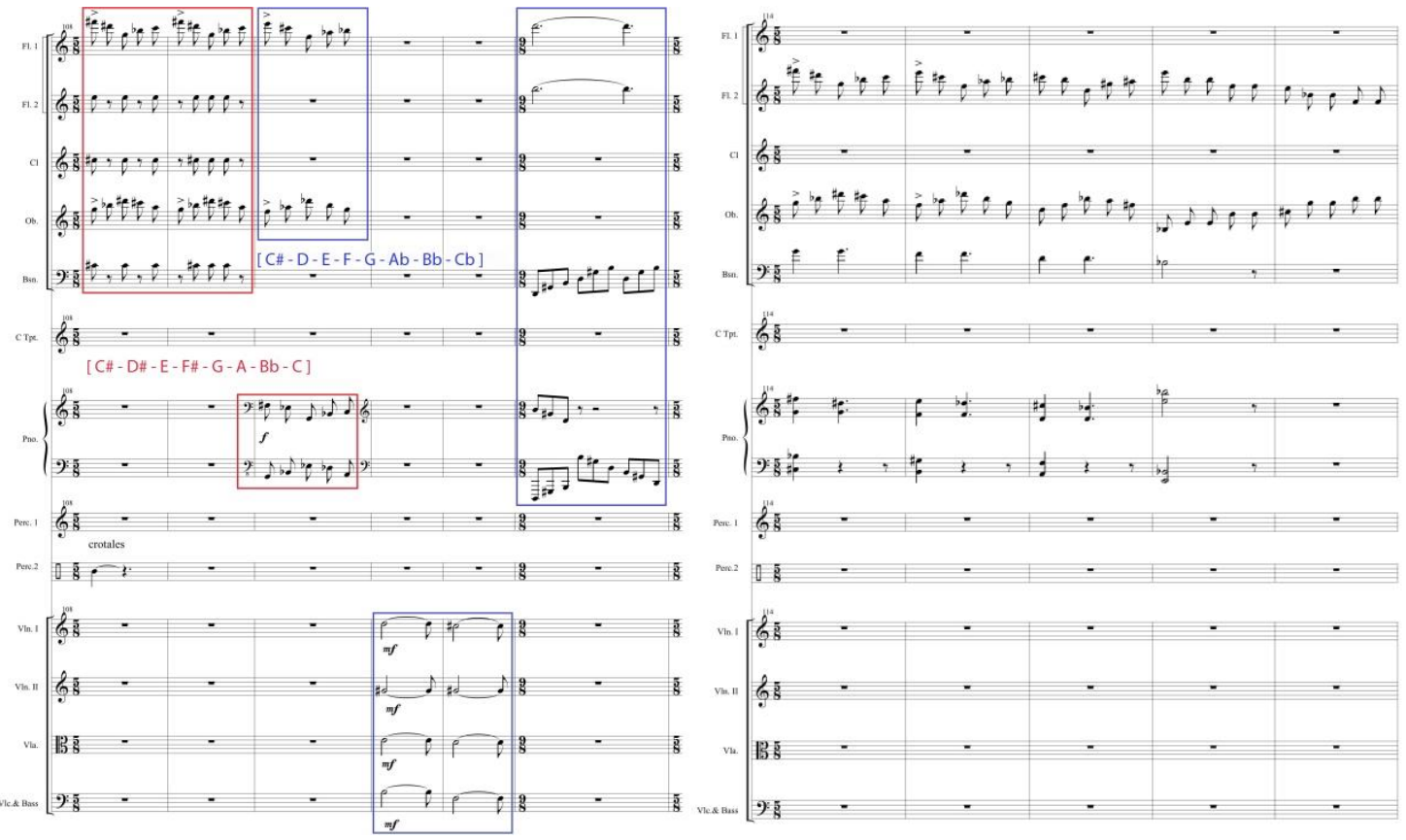

Figure 10: Paulo Costa Lima, Atotô op. 39, excerpt from Section A' (mm. 108 - 118) 
In the dissolution of the basic characteristics of the intertexts - the dorian structure of the song and the rhythmic pattern of the alujá -, one can recognize the progressive reconstruction of the jocular and parodic character of the A section. It culminates when the composite reference is submitted to the polyphonic texture (Figure 11).
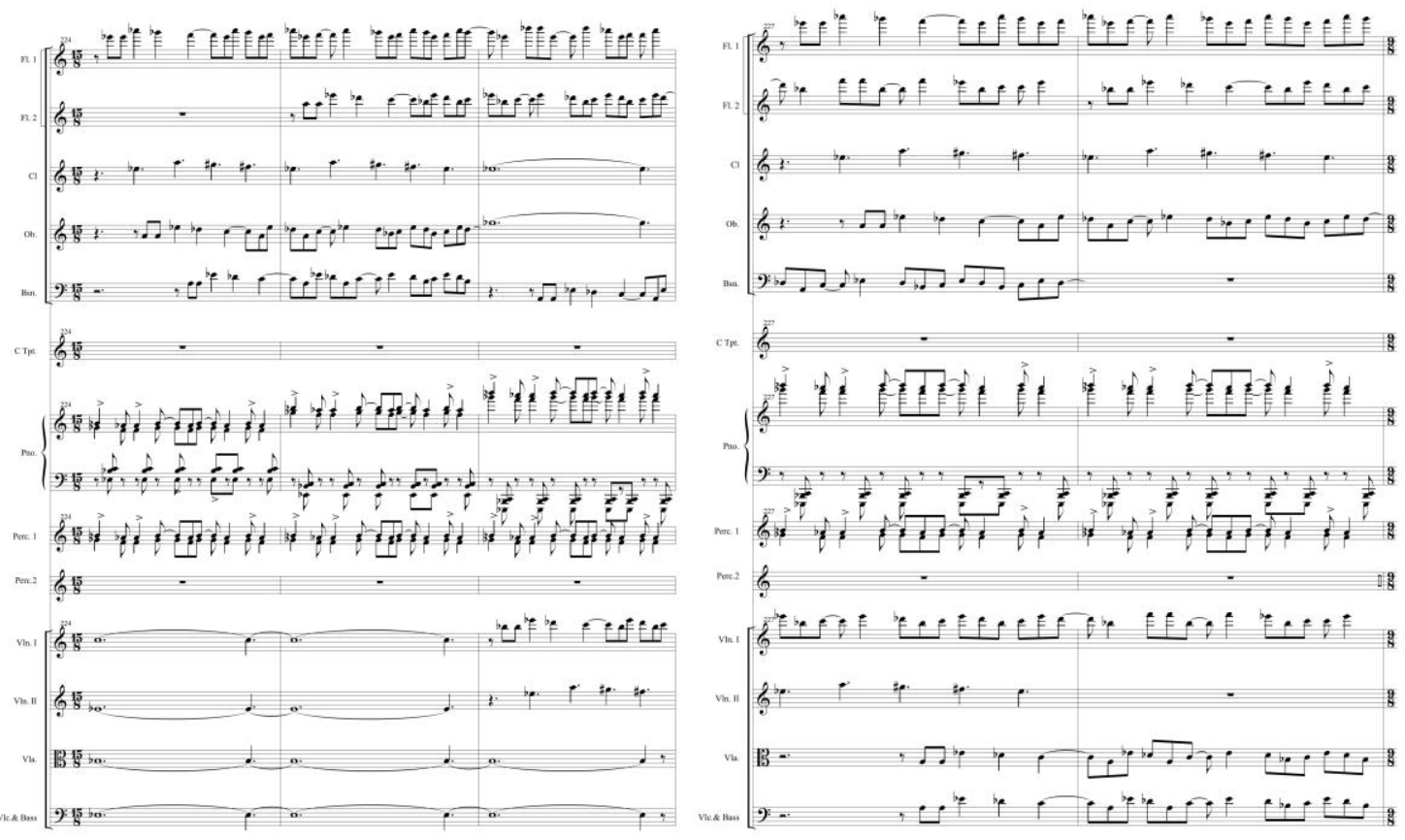

Figure 11: Paulo Costa Lima, Atotô op 39, excerpt from Section A' (mm. 224 - 228)

The framing of the "knight-orisha" with the predictable technicality of the canon endows this section with a seriousness diametrically opposed to the ironic humor implicit in the dense homophonies of the A section. Notice, then, how the play of textures acquires in this piece an expressive and representative value, setting up topological structures of the discourse. In fact, the textural elaboration is meaningful to the comprehension of the piece according to its poetic argument ("peace building via differences"). The polyphonic excerpt of Figure 11 in the beginning section would not make sense, just as the return of the danceable homophonic texture would be incoherent in the concluding section. An implicative, conducive and linear development is thus understood, which is formed through the texture and the general form of the piece. However, the contiguous small-scale structures do not interact in "syntactic" terms (although they do concern the gestalt of the design). The piece concludes by remembering its beginning: the berimbau improvisation survives the orchestra's final chord, referring to the cultural scenario (Figure 12). 


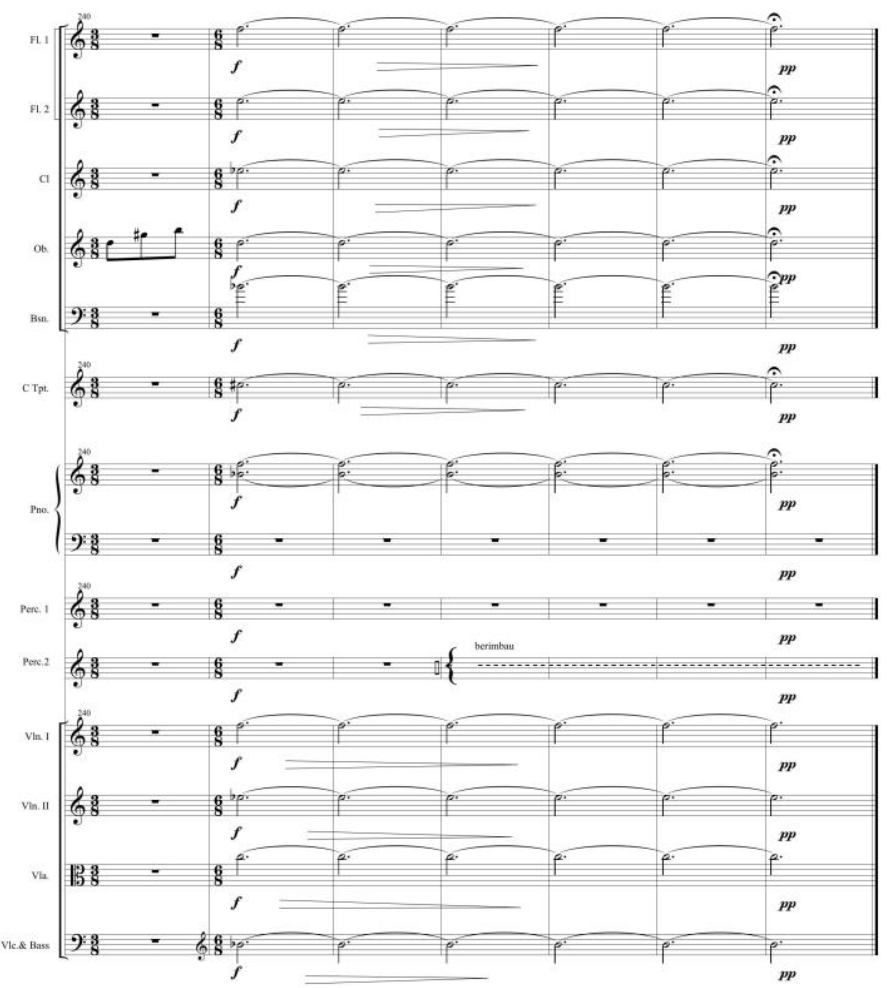

Figura 12: Paulo Costa Lima, Atotô op. 39, final measures

Using a canonical structural model with the great force of seduction for the narrative fantasy (the $\mathrm{ABA}^{\prime}$ form), the formal concept seems to be at the service of the poetic argument: the dialogue between the warrior ancestors, proposing the peace building via differences. Meanwhile, if the large-scale structure seems to serve the narrative of the ideological program, the small-scale structures are the opposite of this perspective, because the constant variation challenges the apprehension of the references. In the step-by-step musical evolution, the listener's attention tends to get confused by the multiplicity and transience of the successive variants and therefore, in the compositional "becoming." It could be said that while a potentially narrative structural ideology guides the remote structural level, the immediate level of the composition destabilizes the substantiation of a narrative construct on the aesthesic plane.

We now turn to the music of Paulo Rios, a student of Paulo Lima since his days as an undergraduate until the completion of his doctorate. In his Master's thesis "Cultural Hybridization as a Compositional Method," 14 intertextuality and cultural reference are fundamental strategies in his work with the concept of hybridism.

In his Música Peba No. 1 (Qual?), composed in 2010 for mixed quintet (fl., cl. vn., gtr., pf.), two antagonist aesthetic prototypes interact in the musical conception: the dodecaphonic pointillism of the Second Viennese School, and the rhythmized miudinho of forró. ${ }^{15}$ The models are materialized in an intertextual concept built on the song "Schatzerl klein" (Opus 18 No. 1) by Anton Webern and 
of the forró song "Você não vale nada, mas eu gosto de você" (You are Unworthy, but I Like You) by Dorgival Dantas.

Cycles of advancement and retreat of reference materials define the compositional syntax, revealing each reference in the foreground or background. Contrary to what we see in Paulo Lima's music, where the appropriated elements (the melodic line and the rhythmic pattern) are found in a state of fusion, in the work of Paulo Rios, the intertexts dialogue without losing identity.

The example in Figure 13a shows a phrase which begins with a reference to the forró song (pf., mm. 23-24) and ends with a quote from the piece by Webern (gtr., mm. 26).

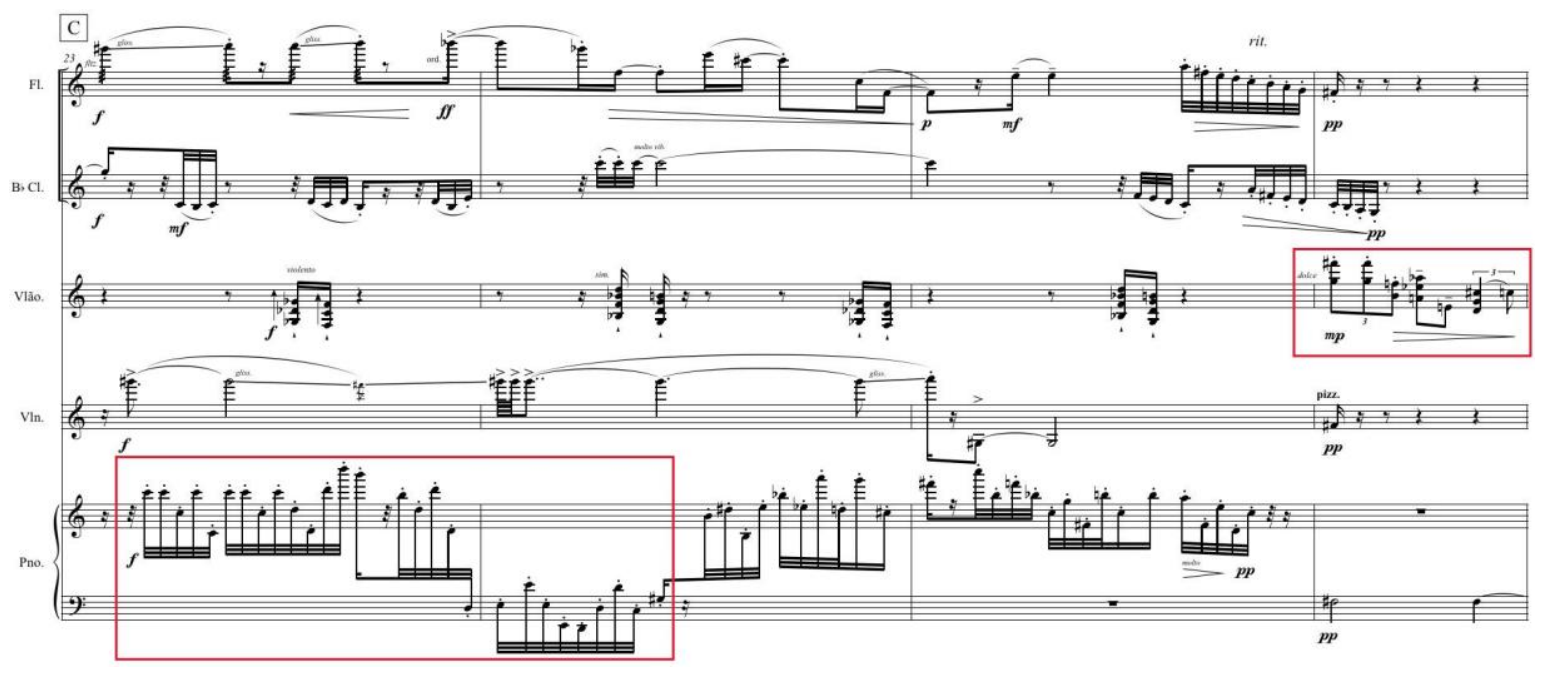

Figure 13a: Paulo Rios Filho, Música Peba No. 1, mm. 23 - 26

In the following phrase (Figure 13b), we see the inverse order in the references.

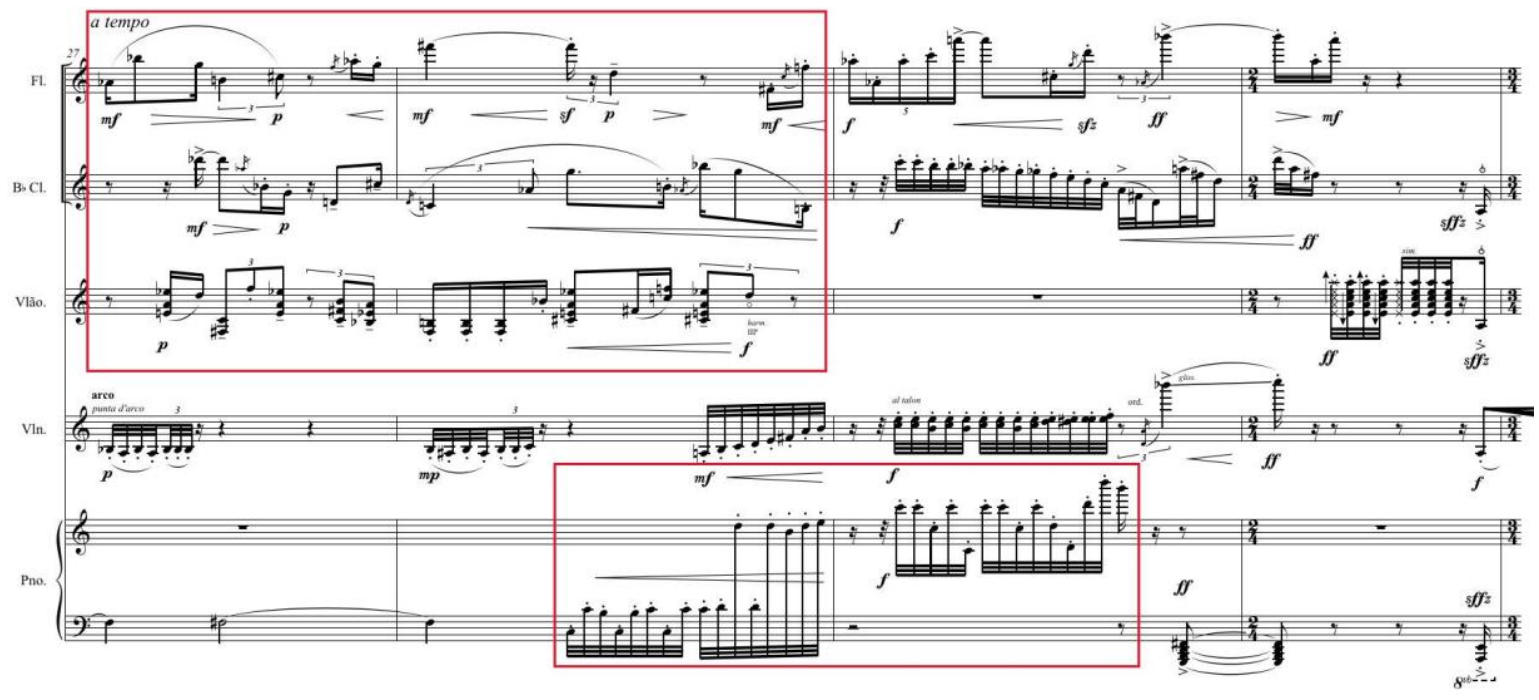

Figure 13b: Paulo Rios Filho, Música Peba N.ำ 1, mm. 27 - 30 
The sequence of these two phrases exemplifies the cycles of advancement and retreat of reference materials. However, in the whole trajectory of the piece, what happens is a progressive change in the predominance of the references. In the beginning (Figure 14a), one can observe the weight of the Webern references. Over time, this is gradually won over by the progressive audibility and cognition of the Brazilian-Northeastern referent (forró), which dominates the end of the piece (Example 14b). The change of the predominance of referents may be considered a dramatic argument stimulating the analytical comprehension of the piece by the bias of narrativity. In this case the intertexts, with their symbolic potential, function as semantic entities, that is, as "musical agents" in the process of a narrative listening guided by the transvaluation of the "markedness" and "rank" 16 of these agents in the temporality of the work.

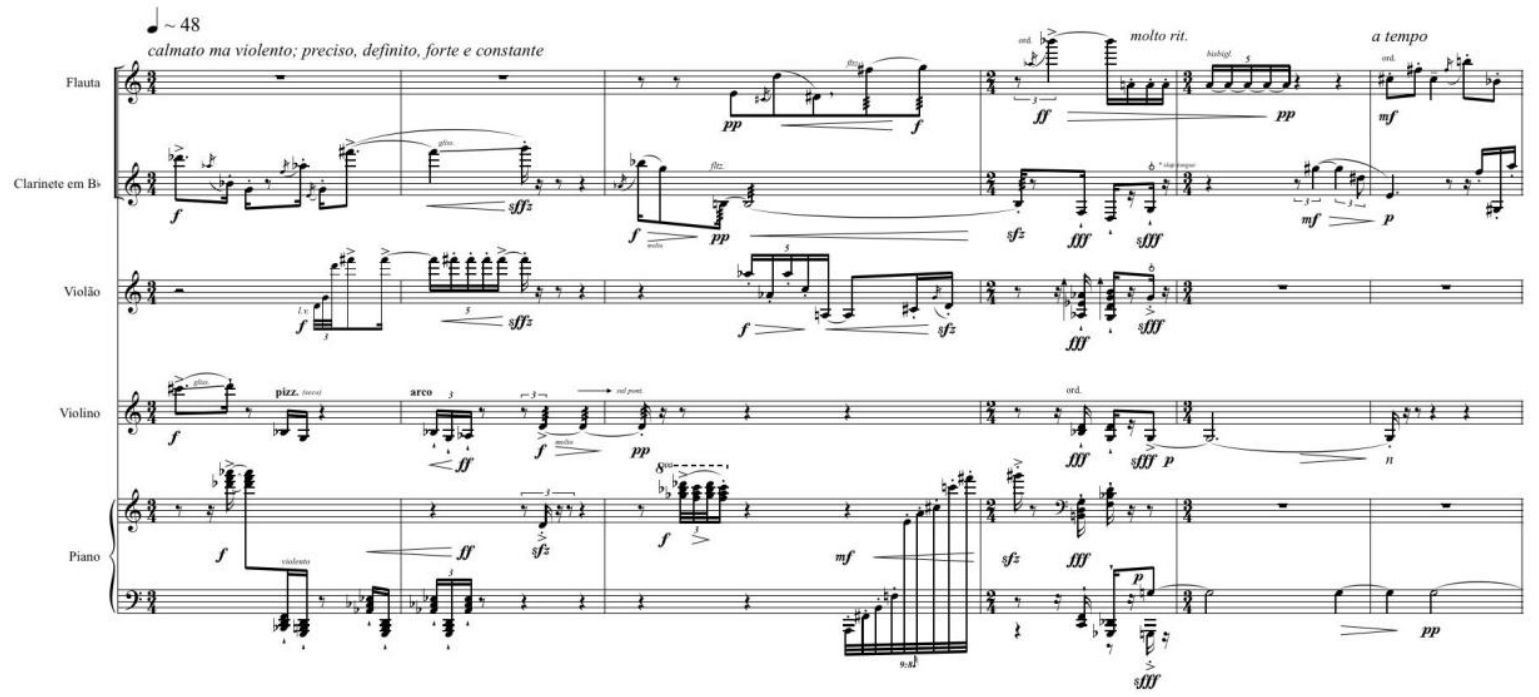

Figure 14a: Paulo Rios Filho, Música Peba N.ํo 1, mm. 1 - 6

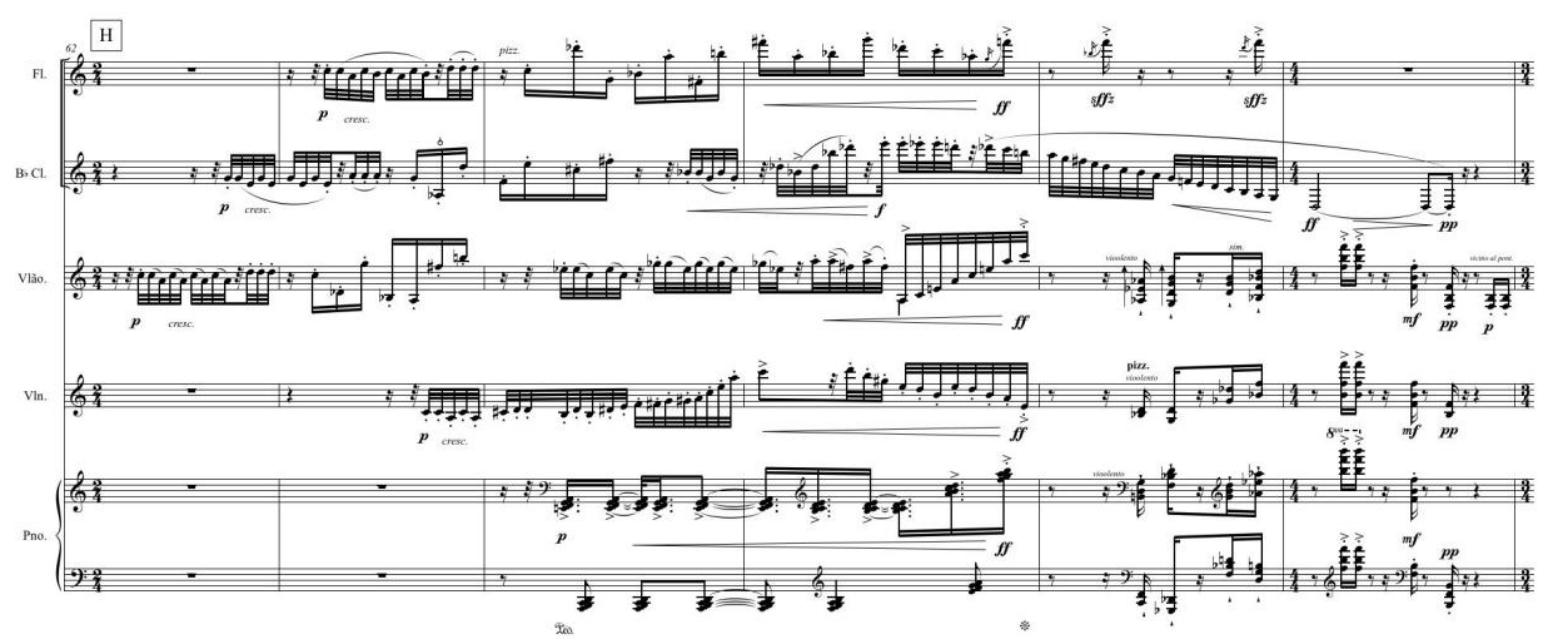

Figure 14b: Paulo Rios Filho, Música Peba No. 1, mm. 62 - 67 


\section{4 - Ethics and Paradigms in Musical Creation}

Referring these brief analytical considerations to the strategic aspects, which guide knowledge production, we can arrive at the following conclusions about the structural values and principles of contemporary composition, here considered in the specific field of Bahian music.

The analytical point of view of Widmer's Duo, which corresponds to the piece, is structuralist. Demonstrating the saturation of the generative motive in multiple forms, by rhythmic augmentation and diminution, by inversion, retrograde and transposition of pitches, in sequenced or nested events in texture, we refer to the argument of the work, to the essence of its poiesis. The various techniques of motivic derivation that generate themes are the production strategy of the type of compositional knowledge, which reigns over the work: organicism, the system based on the logic of reproduction, whose organizing memory is reflected in established relations among the distinct hierarchical levels of the structure. Therefore, the arboreal model of knowledge production is evident in the work.

Thirteen years separate the composition of Widmer's Duo from Paulo Lima's Atotô, a work in which a structural analysis does not make sense. No structural analytical method (from the point of view of pitch or rhythmic organization) can track a systematic thought and arrive at a convincing result about any knowledge of grammatical order. All attempts will quickly fail, because the composition challenges the concept of structuralism. It is through the perception of the symbolic value of the appropriations and cultural references that we can embark on understanding the piece. Guided by the sketch of the ideological meaning shown by the composer, we can follow the clues of its potential narrative. Revitalizing the cyclical model, the large-scale formal prototype develops in a proposition of linearity and turnover. A relationship of causality between before and after is important in the perception of a united and complete aesthetic that corresponds to the organic structures, to the arboreal model of knowledge. Nonetheless, the discursive strategy in the small-scale relations, not implicative in their lines of flight, operates a deconstructionist critique of the hegemonic standard, as a proposal of demythologization. The arboreal and rhizomatic knowledge models correspond, respectively, to the structural project and the musical discourse, concerning different hierarchical levels of the composition.

Finally, the "Música Peba" of Paulo Rios reminds me of something said by the elderly Smetak (1985): "Brazil is a land of possible impossibilities, in which in the future, a new order and logic will materialize." Neither "order" nor "logic" seems to materialize in this piece in the conventional sense. However, if order and logic are conditions for the perception of a single whole, we must admit that 
this is what the work makes us understand: a totality, which projects organically, due to the stability of the two materials - however, in a new concept of organicity, as predicted by Smetak. The project of "Música Peba" can be understood as an unfolding of a temporality in a sequence of segments aesthetically self-similar. This sequence is liable to be modified without causing influence on the comprehension of an ideological signification which insinuates itself in the tangling and untangling of the paradoxical, culturally antagonistic intertexts. "Música Peba No. 1" can be described as a circulation of variants in the process of becoming; as a structure potentially open to internal reshuffling and, at the same time, closed in the duality of the referents, which project multiple dialogical configurations. Despite the fact that they identify in content and configuration, the various and defined segments of music do not compose an implicative syntax. In other words, they are not submitted to any law of contiguity. One can say, therefore, that the compositional project emulates the transverse relations of the rhizomatic model of knowledge production.

Notwithstanding the distinctions pointed out, one can recognize in the three pieces evidence of affiliation to a dominant ideology impregnated with local culture and, at the same time, subject to strategies of structural conception of a universal character. One can recognize that the subjective experiences of the Bahian composers, in a certain measure, divert from the model of reasoning and communication fundamented in technological expertise and in the gravitation of processes of universal character. In this way, these works deflect from the model, which characterizes contemporary creative thought in general terms. Balancing regional and universal cultural matrixes, Bahian contemporary music admittedly refers to two compositional principles developed by Ernst Widmer, leader in the teaching of composition at the Federal University of Bahia from 1963 to 1987. One principle consists in the parity between "organicity" and "relativization." (Widmer 1988, 1-2.) The first term refers to "the rigorously organic process which results in form"; the second term reports to the "paradoxical reality of "this and that'. Inclusivity in place of exclusivity." The other principle is synthetized in the following quotation:

Time and region define the artist, which defines the region and time. [...] The regional and the universal are not mutually exclusive, quite the opposite: the universal is contained in the regional, its roots; the regional projects itself into the universal, its crown. Both interact, each completing the other (Widmer, 1988).

These driving premises of the compositional processes and the pedagogic practices of Widmer, in my view, define the prevailing subjectification process in Bahian composition, which is singular in the setting of Brazilian contemporary musical culture. It is found in the dialogue between predecessors and successors, and it can be defined as resistance to regulation and to teleology, relativization 
of values, transmutation of concepts. If we recognize one ethos driving compositional knowledge in contemporary Bahia, this is of reciprocity. As for the paradigms, they are all those accommodated in the Bahian cultural melting pot.

"Crisis of contemporaneity," therefore, means much more than what can be understood in the disciplinary domain, in the context of the present, and in the scope of sociologically defined borders. The crisis is set in restraints, gaps, and all sorts of established limits impeding the necessary conciliation between the endogenous and the exogenous, order and chaos, ideologies and utopias. Such conciliation is made indispensable to the understanding of the present as becoming. If, as said by Heraclitus, "panta rhei" (everything flows) and, therefore, "No man ever steps in the same river twice, for it's not the same river," understanding the present demands the apprehension of mutability and transience, the comprehension of the past (testimony) and the preview of the future (responsibility), the compromise of the subject with its world and time: Dasein.

\section{References}

1. Costa Lima, Paulo. 2005. Invenção e Memória. Salvador: EDUFBA.

2. Deleuze, Gilles, and Guatarri, Félix. 1987. A Thousand Plateaus: Capitalism and Schizophrenia. Trans. by Brian Massumi. Minneapolis: University of Minnesota Press. Available at: $<$ http://danm.ucsc.edu/ dustin/library/deleuzeguattarirhizome.pdf $>$ Access in 7/16/2015.

3. Gallo, Sílvio. 1998. "Conocimiento y transversalidade". Proceedings of the Twentieth World Congress of Philosophy, Boston, MA. Available at: "www.bu.edu/wcp/Papers/TKno/TKnoGall.htm", accessed on October 23, 2014.

4. Guatarri, Félix. 1992. Caosmose: um novo paradigma estético. São Paulo: Editora 34. (English version: Chaosmosis: an Ethico-Aesthetic Paradigm, Indiana University Press, Bloomington. Trans. by Paul Bains and Julian Pefanis).

5. Guatarri, Félix, and Rolnik, Suely. 1996. Micropolítica: cartografias do desejo. Petrópolis: Vozes.

6. Kramer, Lawrence. 2014. "In Search of Music: Analysis, Language, and Care." Keynote speech delivered at the First Conference of the Brazilian Association for Music Theory and Analysis (TeMA): Salvador-BA, 11/9-12/2014. Translation into Portuguese by Alex Pochat in O Pensamento musical criativo, ed. I. Nogueira and F. Borém, 2015. Salvador: UFBA, p. 19-39. 
7. Liszka, James Jakób. 1989. The Semiotic of Myth: A Critical Study of the Symbol. Bloomington: Indiana University Press.

8. Paula, João Antônio. 2008. "Apresentação." In A Transdisciplinaridade e os desafios contemporâneos, João Antônio de Paula, org., Belo Horizonte: Editora UFMG, p. 9-16.

9. Smetak, Walter. 1985. “O Alquimista de sons.” Revista Veja, March 5.

10. Touraine, Alain. 2006. Um Novo paradigma: para compreender o mundo de hoje. Petrópolis: Vozes.

11. Widmer, Ernst. 1988. "Identidade da música brasileira”, manuscript, 1 p.

12. 2013. “A Formação dos compositores contemporâneos... E Seu papel na educação musical". Série Marcos Teóricos da Composição Contemporânea na UFBA, vol. IV. Available at: "www.mhccufba.ufba.br/SISMHCC/mhcc_index.php?idioma=pt\&secao=44\&ext $\mathrm{ra}=2^{\prime \prime}$

\section{Notes}

${ }^{1}$ See $<$ http://www.periodicos.ufrn.br/artresearchjournal/article/view/7437/5681>.

${ }^{2}$ Koíoıs / Krisis: action or faculty to distinguish and take decision; by extension, it is the decisive moment, difficult to separate, decide, judge.

3 "For many years there has been identified a crisis of modernity in Music. But, what would be a modernity crisis if not the effervescence and dispersion? The development of modern music led to the questions that exploded with the aesthetic multiplicity and experimentalism of the second half of twentieth century. However, since the 1980s what we see is the ebbing of radicalism. In the twenty-first century, we come upon an open field. On the one hand, expanding the field of music to include sonology created a double challenge: either its concept is less extensive than that of music, a case of the field of music; or its concept is more extensive than that of music, which becomes a case in the multi-expressive sound arts in the globalized world of communication and informational technology. On other hand, concert music seems to need to resume its meaning, striving for an expressiveness that was considered abandoned since modernity.

"The quest we are mentioning is reflected in musicological studies. Assuming that music is a form of communicative or expressive action, recent analytical theories are turning back from structural observation and moving towards hermeneutics, beginning to think of music in the broader context of history, culture and subjectivity. If music analysis between the 1960s and 1980s was considered the base for understanding music, 
today it is believed that understanding music as should be the base - and the limit - of analysis.

"New functions and new meanings of the most diverse music practices have emerged, not only within music creation and musicology, but also in the contemporary setting of music education. The socio-cultural milieu and other areas of knowledge have significantly interacted with music, allowing it to play a beneficial role within problem areas of society and subjectivity. Questions are centered on understanding what effects music can have on the human mind; what benefits or damage does it hold; in what proportions and spheres does it reach humanity and what relationship does it establish with arts, aesthetics, the individual, nature and history - all points of extreme importance to redefine the role and meaning of music in the contemporary world."

${ }^{4}$ According to French sociologist Alain Touraine, the process of subjectification is "a construction, on the part of the individual or the group, of the self as subject" (Touraine 2006:166).

5 The term "ethical" is not used here in the sense of a moral (a group of rules which prescribe standards of behavior in terms of right or wrong), but from an 'ethos,' that is, a way of being and inhabiting the world.

${ }^{6}$ Extracts from "Rhizome," Introduction to the 1st volume of A Thousand Plateaus: Capitalism and Schizophrenia.

${ }^{7}$ Kramer 2014.

${ }^{8}$ Anton Walter Smetak (Zürich, 1913 - Salvador, Bahia, 1984).

${ }^{9}$ As examples of the occurrence of this motive as a structuring element in traditional Northeastern Brazilian music, we can think of the songs Acauã and Juazeiro, from the repertoire of Brazilian singer Luiz Gonzaga.

${ }^{10}$ Quotation from a dialogue between the composer and this author (Jan. 2014).

11 The introduction of the berimbau, as well as melodic and rhythmic appropriations, discreet sonorous objects with independent existence from this composition, can be considered as deictic structures, with localizing function of the discourse in geographic space and historical time.

${ }^{12}$ Double-bladed axe representing the divine weapon of Shango.

${ }^{13}$ In the 10-minute-long recording, this section begins at 3:26 and goes until 6:15.

${ }^{14}$ Rios Filho, Paulo, Cultural Hybridization as a Methodological Horizon for the Creation of Contemporary Music, Master's thesis, School of Music, UFBA, 2010.

${ }^{15}$ Forró is a genre of Brazilian Northeastern folk dance and music which encompasses various styles. Miudinho, one of the most popular styles of forró, derives its name from the fact that it is danced in the same place (mobility beeing gained through spinning).

16 "Markedness" and "rank": terms of the theory of narrative of J. J. Liszka (1989, p. 62). 